\title{
Peran Guru Dalam Menumbuhkembangkan Kemandirian Siswa Melalui Pembelajaran Inkuiri
}

\author{
Hany Lusia Damayanti ${ }^{1}$, Aurel Anastasia Anando ${ }^{2}$ \\ 1, 2, Universitas Indraprasta PGRI, Indonesia \\ ${ }^{1}$ hanylusi15@gmail.com; ${ }^{2}$ anastasiaarl22@gmail.com
}

\begin{abstract}
Abstrak
Tujuan dari artikel ini untuk mengetahui kemandirian siswa melalui pembelajaran inkuiri secara daring. Metode yang digunakan dalam penelitian ini adalah studi pustaka dengan menganalisis artikel yang telah diterbitkan secara online oleh peneliti sebelumnya. Berdasarkan hasil analisis artikel dapat disimpulkan bahwa kemandirian belajar siswa merupakan hal penting dimana siswa harus berperan aktif dalam proses pembelajaran. Dalam menumbuhkembangkan kemandirian siswa, siswa dapat mengubah tingkah laku dalam hal mengamati, membaca, meniru, menyimak, berpikir kritis dan menggunakan gaya belajar untuk menggali minat dan kemampuannya. Untuk mengembangkan kemandirian siswa dalam model pembelajaran inkuiri yang diterapkan oleh guru ke siswa sesuai dengan sintak yaitu: a). Siswa dianjurkan dalam mengamati fenomena kejadian yang memberikan pengalaman belajar; b). Pendidik memberikan pertanyaan kepada siswa mengenai fenomena yang di hadapi dari berbagai sumber; c). Pendidik mengajukan pertanyaan kepada siswa untuk melatih berfikir dalam melakukan penalaran mengenai pertanyaan yang diberikan oleh pendidik; d). Mengumpulkan pertanyaan-pertanyaan yang diajukan oleh pendidik; e). Membuat kesimpulan berdasarkan pertanyaan yang di berikan oleh pendidik yang telah diolah.
\end{abstract}

Kata Kunci: Kemandirian, Model Pembelajaran, Model Inkuiri

\section{Pendahuluan}

Pendidikan merupakan faktor penting yang ada dalam kehidupan manusia dalam membentuk karakter suatu bangsa untuk maju ke arah kehidupan yang lebih baik. Pendidikan dapat mengarahkan manusia untuk mengembangkan potensi, pengetahuan, keterampilan, kemandirian, kreativitas dan kemampuan yang dimilikinya dalam mencapai kompetensi yang diharapkan. Menurut peraturan pemerintahan di Indonesia yang terdapat pada Undang Undang No 20 Tahun 2003 tentang Sistem Pendidikan Nasional sebagai salah satu bukti bahwa peran pemerintah peduli terhadap peningkatan kualitas masyarakat yang berada disekitarnya. Undang-undang No 20 tahun 2003 menjelaskan tujuan Pendidikan Nasional yaitu mengembangkan potensi diri siswa dalam proses pembelajaran yang berlangsung baik melalui jalur pendidikan formal dan jalur pendidikan informal (S. Rahmayanti, 2017).

Guru merupkan unsur penting dalam proses Pendidikan, seperti yang dijelaskan dalam Undang - Undang no 14 tahun 2005, bahwa guru merupakan seorang pendidik yang profesional yang memiliki tugas dalam mendidik, membimbing, mengajar, melatih, mengarahkan, menilai dan mengevaluasi sejauh mana kemampuan siswa dalam memahami 
materi pembelajaran yang terjadi dalam proses belajar dari mulai tangka pendidikan usia dini sampai menengah. Berdasarkan hal tersebut, maka guru memiliki peran penting dalam membentuk potensi siswa melalui proses pembelajaran yang menarik secara langsung maupun tidak langsung memberikan stimulus atau rangsangan kepada para siswa untuk lebih aktif dan memahami materi pembelajaran apa yang disampaikan oleh guru.

Kondisi pembelajaran akibat munculnya pandemi covid-19 mengakibatkan proses pembelajaran menjadi terganggu, maka pemerintah Indonesia mengambil kebijakan yang mengharuskan pembelajaran daring supaya proses pembelajaran tetap dilakukan walaupun jarak jauh, upaya kebijakan yang di ambil pemerintah untuk memutus rantai penyebaran virus Covid-19 yang terjadi di kalangan masyarakat. pembelajaran daring yang diterapkan oleh pemerintah diberlakukan dari jenjang TK hingga Perguruan Tinggi. Pembelajaran daring yang dilakukan dirumah dengan bimbingan orang tua. Dalam pelaksanaan pembelajaran daring orang tua memiliki kendala, yaitu merasa kesulitan dalam memahami materi dan kurang sabarnya orang tua dalam mendampingi dan membimbing anaknya belajar, kesulitan orang tua dalam mengoprasikan gadjet, dan kendala kuota internet. Kendala pembelajaran daring tersebut menimbulkan kemandirian dan minat belajar siswa menjadi menurun. Minat belajar dan kemandirian yang menurun, menyebabkan terganggunya prestasi untuk mendapat nilai terbaik dalam mencapai keberhasilan (Sulistyawati, 2020).

Dalam meningkatkan kualitas pembelajaran di sekolah, ada beberapa faktor penting yang harus diperhatikan seperti: Pendidik (guru), siswa, sarana dan prasarana dan lingkungannya. Diantara faktor penting tersebut guru dan siswa merupakan komponen utama dalam meningkatkan pembelajaran disekolah (Rumithi et al., 2017). Salah satu faktor penting yaitu adanya oeran guru (pendidik). Peran guru dalam kondisi pandemi Covid-19 sangat diperlukan karena, dapat memotivasi siswa bersemangat dalam belajar dan percaya diri atas kemampuannya, siswa dapat menyelesaikan masalah - masalah yang terjadi pada saat proses pembelajaran secara daring. Adanya peran pendidik (guru) yang memotivasi siswa, membuat siswa membuat siswa mampu menjadi aktif dan kreatif dalam proses belajar dan memecahkan masalah (Rahmawati et al., 2019).

Pada saat proses pembelajaran secara daring, siswa diharapkan mempunyai kemandirian dalam belajar. Kemandirian belajar pada siswa masih menjadi permasalahan dalam pembelajaran. oleh karena itu, siswa dituntut untuk mulai belajar mandiri. Dengan belajar mandiri, siswa dapat beraktivitas tanpa bergantung terhadap orang lain. Akan tetapi, kemandirian yang muncul pada diri siswa seperti siswa dapat mengembangkan potensi, pengetahuan dan kreativitasnya sesuai dengan apa yang dipahaminya.

Menurut Slameto (2003) "Kemandirian Belajar adalah belajar yang dilakukan dengan sedikit atau sama sekali tanpa bantuan dari pihak luar". Sedangkan menurut Umar dan Sulo (2005) pendorong aktivitas belajar berasal dari kemauan sendiri dalam pembelajaran. Kemandirian belajar pada siswa pendidikan menengah memerlukan berbagai strategi dan aktivitas untuk memfasilitasi siswa dalam mengambangkan potensi yang dimilikinya. Aktivitas tersebut dapat dilakukan dengan cara membantu siswa mengenali dirinya sendiri dengan lingkungannya, agar mampu mengarahkan dirinya sendiri dan akhirnya dapat memecahkan masalah yang mungkin akan dihadapinya nanti supaya siswa mampu menjadi individu yang mandiri. Strategi yang diterapkan dalam kemandirian belajar dapat digunakan melalui penggunaan media, permainan dan strategi kreatif yang menarik siswa yang dapat diterapkan dalam kemandirian belajar (Subekti \& Yunuarto, 2008). 
Salah satu upaya yang dapat dilakukan untuk mengatasi rendahnya kemandirian belajar dan minat belajar pada saat pembelajaran secara daring yaitu dengan mengubah metode pembelajaran yang akan diberikan oleh pendidik, sehingga siswa mudah dalam memahami materi pembelajaran dan siswa dapat berperan aktif dalam proses pembelajaran (Sulistyawati, 2020). Metode pembelajaran yang sesuai dengan kemampuan berpikir pada siswa adalah metode inkuiri terbimbing, karena metode pembelajaran inkuiri terbimbing mampu mengembangkan pemahaman konsep materi kepada siswa dalam proses berpikir kritis. Pembelajaran inkuiri terbimbing merupakan suatu model pembelajaran yang menanamkan dasar - dasar berpikir ilmiah pada siswa, karena model pembelajaran inkuiri terbimbing mampu meningkatkan kreativitas siswa dalam memecahkan masalah, sehingga siswa mampu memiliki sikap kemandirian dalam belajar. Peran pendidik pada metode pembelajaran inkuiri terbimbing sangat diperlukan untuk memotivasi siswa dalam menyelesaikan masalah - masalah yang terjadi dalam proses pembelajaran. Dengan peran pendidik yang memotivasi siswa, membuat siswa mampu menjadi aktif dan kreatif dalam proses belajar dan memecahkan masalah (Rahmawati et al., 2019).

\section{Metode}

Metode penelitian yang dilakukan adalah studi pustaka atau telaah pustaka. Dengan mencari referensi literatur - literatur yang relevan yang berhubungan dengan pembelajaran inkuiri yang dikaji lebih mendalam dengan cara mendiskusikan dan mengevaluasi penelitian sebelumnya. Metode studi pustaka atau telaah pustaka merupkan suatu kajian ktitis dengan atas pembahasan suatu topik yang sebelumnya sudah di tulis oleh para ilmuwan dan peneliti sebagai sumber informasi yang biasanya dapat berupa jurnal - jurnal, e-book, buku dan artikel ilmiah yang lainnya. Metode studi pustaka yang penulis pakai bertujuan untuk mengungkapkan teori - teori yang relevan yang sesuai dengan permasalahan yang dihadapi dan diteliti dalam penelitian. Dalam membuat penelitian ini, penulis melakukan pengumpulan berbagai macam artikel yang dijadikan referensi, menganalisis artikel yang diperoleh berdasarkan permaslahan yang dihadapi dan diteliti dalam penelitian, menyimpulkan hasil telaah pustaka dari berbagai macam artikel yang dijadikan referensi untuk mengetahui menumbuhkembangkan kemandirian siswa melalui pembelajaran inkuiri.

\section{Pembahasan}

\section{Kemandirian Siswa}

Kemandirian belajar adalah salah satu masalah dalam pembelajaran. Kemandirian belajar merupakan proses belajar mandiri tanpa bergantung dengan orang lain. Menurut Abriyani (2012) kemandirian belajar adalah proses belajar mandiri, tanpa bantuan orang lain, dalam merumuskan tujuan belajar, mengetahui sumber - sumber belajar dan mengevaluasi hasil belajar yang dilakukannya (Nuriali et al., 2018). Kemandirian belajar siswa merupakan hal penting dimana Siswa dituntut aktif dalam proses pembelajaran pada saat sebelum dan setelah proses pembelajaran, karena siswa yang sudah mempelajari dan memahami materi pelajaran sebelum proses pembelajaran dimulai membuat siswa mampu mendapatkan prestasi yang baik dan mampu merubah tingkah laku siswa dalam hal mengamati, membaca, meniru, menyimak, berfikir kritis, dan menggunakan gaya belajar yang siswa punya serta mengggali minat dan kemampuan mereka menggunakan kecerdasan yang mereka miliki (Erita, 2017). 
Kemandirian belajar merupakan faktor penting yang dapat diterapkan pada pembelajaran tatap muka dan pembelajaran daring, karena kemandirian belajar berkaitan dengan belajar mandiri bukan berarti siswa belajar sendiri melainkan siswa boleh bertanya dan berdiskusi kepada pendidik, orang tua atau orang lain dalam meningkatkan proses pembelajaran agar tercapainya kemampuan dan peningkatan dalam belajar (Erita, 2017).

Akibat Pendemi Covid-19 pemerintah menetapkan proses pembelajaran jarak jauh secara daring. Pembelajaran daring tersebut mengharuskan siswa untuk melakukan pembelajaran di rumah masing - masing. Penerapan pembelajaran Jarak jauh dilakukan oleh pendidik dengan cara memberikan materi pelajaran dengan perantara teknologi internet. Oleh karena itu, keberhasilan dipengaruhi oleh kemandirian dalam belajar dan metode pembelajaran yang pendidik terapkan kepada siswa. Kemandirian belajar pada pembelajaran daring ini membuat kemandirian belajar siswa menurun dan siswa memiliki tanggung jawab dalam belajar yang termasuk dalam ciri - ciri kemandirian dalam belajar. Ciri - ciri kemandirian tersebut yaitu adanya rasa percaya diri, tidak bergantung pada orang lain, berani mengambil keputusan dan mampu memecahkan masalah (Arif et al., 2021).

Penyebab rendahnya kemandirian belajar pada siswa pada saat pandemi covid - 19, maka pendidik harus membuat suatu inovasi dalam pembelajaran supaya kemandirian belajar siswa dapat terwujud. Salah satu cara dalam meningkatkan kemandirian dalam belajar siswa pada pembelajaran daring dan tatap muka adalah menerapkan model pembelajaran untuk membangun suasana belajar sehingga siswa dapat mengeksplorasi, berfikir kritis dan mampu mengembangkan potensi yang dimilikinya. Adanya model pembelajaran inkuiri terbimbing yang diterapkan kepada siswa mampu mengembangkan konsep materi yang disampaikan oleh pendidik (Ganesha, 2019). Rendahnya kemandirian belajar terhadap siswa, maka siswa memerlukan adanya motivasi yang mampu mengembalikan semangat belajar meskipun melalui pembelajaran daring, supaya siswa tetap semangat dalam proses belajar dan kemandirian belajar.

\section{Pembelajaran Inkuiri}

Model Pembelajaran inkuiri merupakan model pembelajaran yang mampu meningkatkan kemandirian belajar siswa. Model pembelajaran inkuiri dapat membantu siswa dalam meningkatkan kemampuan ingatan dan kemampuan dalam memahami pelajaran karena model pembelajaran inkuiri dapat membantu siswa dalam memecahkan masalah dalam belajar. Pembelajaran inkuiri ini siswa di dorong untuk menggali informasi dari berbagai sumber - sumber referensi. Pendidik berharap dengan menerapkan model pembelajaran inkuiri kepada siswa, siswa dapat meningkatkan kemandirian dalam belajar dan menghilangkan pembelajaran konvensional (Ika et al., 2018).

Peran pendidik (guru) dalam model pembelajaran inkuiri sangat penting. karena, pendidik dapat membantu dan memberikan kemudahan dalam belajar serta memotivasi siswa dalam belajar. Menurut Kuhlthau jika model pembelajaran inkuiri tidak diterapkan kepada siswa tanpa bimbingan guru, maka akan menimbulkan kekacauan. Sehingga model pembelajaran inkuiri dapat dilaksanakan dan diterapkan kepada siswa secara optimal dengan bimbingan dari pendidik (guru) yang diberi istilah dengan Guided Inkuiri (Inkuiri Terbimbing) (Juniati \& Widiana, 2017). 
Model pembelajaran inkuiri terbimbing diartikan sebagai model pembelajaran yang mana siswa melakukan proses pembelajaran sendiri dan model pembelajaran inkuiri terbimbing mampu mengembangkan pola berfikir siswa dan menanamkan dasar - dasar berfikir ilmiah agar siswa mampu berkreativitas dan mengembangkan potensinya dalam dirinya. Oleh karena itu, model pembelajaran inkuiri terbimbing mampu membantu siswa dalam mengembangkan pemahaman konsep siswa. Siswa merupakan subjek dalam model pembelajaran ini, supaya siswa memiliki kemandirian dalam belajar. Model pembelajaran inkuiri terbimbing (guided inkuiri) merupakan suatu model pembelajaran yang menjelaskan mengenai keterkaitan antara objek dan peristiwa. Pembelajaran inkuiri terbimbing membantu siswa dalam memberikan kesempatan dan pengalaman. Oleh karena itu, pembelajaran inkuiri dapat membantu siswa dalam menyusun konsep - konsep materi apa saja yang akan dipelajari melalui proses berpikir kritis dalam model pembelajaran inkuiri terbimmbing (Rumithi et al., 2017). Proses berpikir kritis dalam model pembelajaran inkuiri dapat siswa lakukan dengan mencari, mengevaluasi dan menganalisis berbagai sumber - sumber informasi dari berbagai sumber - sumber referensi (Erita, 2017).

Bentuk pembelajaran inkuiri terbimbinng bisa diberikan oleh pendidik (guru) dengan cara memberikan motivasi kepada siswa untuk menyelidi dan mengatasi masalah - masalah yang muncul dalam belajar. Dengan pendidik (guru) memberikan motivasi kepada siswa dalam pembelajaran dapat membuat siswa bersemangat dalam belajar dan percaya diri atas kemampuannya serta siswa bisa menjadi anak yang aktif dan kreatif dalam proses pembelajaran (Rumithi et al., 2017).

\section{Pembentukan Kemandirian Siswa Melalui Pembelajaran Inkuiri}

Kondisi pada massa pandemi covid 19, pemerintah menghimbau untuk melakukan proses pembelajaran secara daring. Pembelajaran yang dilakukan secara daring membuat siswa kesulitan dalam memahami materi pelajaran dan kurangnya motivasinya dalam belajar. Untuk meningkatkan kemandirian siswa dalam proses pembelajaran secara daring dibutuhkan sikap tanggung jawab, memiliki insiatif dalam berpikir, memiliki tekad yang kuat dalam memecahkan suatu masalah. Pendidik (guru) berharap siswa dapat menjadikan dirinya sebagai seorang pelajar, agar bisa tekun dan giat selama proses pembelajaran secara daring. Pembelajaran secara daring membuat kesadaran dalam pembentukkan kemandirian siswa menurun. Karena, siswa tidak memiliki motivasi dalam belajar secara mandiri, tidak bersungguh-sungguh dalam belajar dan tidak bertanggung jawab terhadap tugas yang diberikan guru. Apabila siswa memiliki kemandirian belajar yang ada dalam dirinya, maka siswa dapat memecahkan masalah-masalah tersebut dan memiliki keinginan dan pengetahuan yang membuat siswa mampu tumbuh, maju dan berkembang dalam mencapai kesuksesan (Saputra et al., 2020).

Upaya yang dapat pendidik (guru) lakukan dalam membentuk kemandirian siswa yaitu dengan membuat suatu rancangan dalam proses belajar dengan cara menerapkan model pembelajaran inkuiri yang dapat membentuk siswa menjadi mandiri dan termotivasi dalam belajar. Model pembelajaran inkuiri merupakan model yang cocok diterapkan kepada siswa untuk membangkitkan kemandirian belajar siswa, memperluas dan menambah wawasan pengetahuann serta daya fikir siswa. Agar, siswa bisa berfikir secara kritis dan ilmiah dalam belajar. Peran seorang pendidik (guru) dalam model pembelajaran inkuiri sangat diperlukan karena, pendidik (guru) bisa memberikan motivasi kepada siswa agar mampu mengembalikan 
semangat belajar dan bisa belajar lebih giat dan mandiri walaupun proses pembelajaran dilakukan secara daring (Sugianto et al., 2020).

Model pembelajaran inkuiri yang diterapkan oleh Pendidik (guru) kepada siswa melalui pembelajaran secara daring sesuai dengan sintak yaitu: (a). Siswa dianjurkan dalam mengamati fenomena kejadian yang memberikan pengalaman belajar. Hal tersebut dilakukan oleh pendidik dengan cara membimbing siswa agar dapat mengidentifikasi fenomena kejadian yang terjadi sesuai dengan aturan yang berlaku agar dapat membentuk kemandirian siswa; (b). Pendidik (guru) memberikan pertanyaan kepada siswa mengenai fenomena yang dihadapi dari berbagai sumber. Dalam hal ini, siswa diharapkan mampu menjawab pertanyaan yang diberikan oleh pendidik (guru) dan menjelaskan fenomena yang dihadapinya dari berbagai sumber. Hal tersebut membuat siswa bisa mengembangkan pengetahuannya. Sehingga, siswa bisa memahami materi yang diberikan oleh pendidik (guru); (c). Pendidik (guru) mengajukan pertanyaan kepada siswa untuk melatih berpikir dalam melakukan penalaran mengenai pertanyaan yang diberikan oleh pendidik (guru). Hal tersebut dilakukan oleh pendidik agar siswa memiliki daya ingat yang kuat supaya bisa berperan aktif dalam proses pembelajaran; (d). Mengumpulkan pertanyaan-pertanyaan yang diajukan oleh pendidik. Hal tersebut bertujuan agar siswa pertanyaan-pertanyaan tersebut di diskusikan secara kelompok agar memperoleh informasi; (e). Membuat kesimpulan berdasarkan pertanyaan yang diberikan oleh pendidik yang telah diolah. Upaya tersebut dilakukan oleh pendidik (guru) membimbing siswa agar dapat membuat kesimpulan yang baik dan benar (Asmuni, 2021).

Berdasarkan pemaparan teori di atas, maka sintaks model pembelajaran inkuiri yang sesuai melalui pembelajaran daring yaitu : (1) Adaptasi, pendidik (guru) dan siswa diharapkan bisa beradaptasi dengan metode pembelajaran secara daring yang menggunakan teknologi untuk kegiatan belajar mengajar; (2) Pendidik (guru) memberikan pertanyaan kepada siswa melalui aplikasi belajar online seperti google classroom. Dalam hal ini, siswa diharapkan mampu menjawab pertanyaan yang diberikan oleh pendidik (guru) dan menjelaskan fenomena yang dihadapinya melalui aplikasi pencarian online yang tersedia; (3) Mengumpulkan pertanyaan, dengan ini siswa bisa mendiskusikannya secara berkelompok melalui aplikasi WhatsApp untuk mengetahui jawaban yang diberikan oleh pendidik (guru); (4) Membuat kesimpulan atas jawaban yang sudah siswa cari lalu mengumpulkannya kembali kepada pendidik (guru) melalui aplikasi Google Classroom (Sugianto et al., 2020).

Pendidik (guru) dalam pembelajaran secara daring menggunakan aplikasi belajar seperti google classroom. Aplikasi google classroom digunakan oleh pendidik (guru) untuk memberikan pertanyaan. Pertanyaan tersebut diberikan oleh pendidik agar melatih siswa bisa beripikir secara ilmiah dan kritis. Dalam hal ini, siswa juga diharapkan mampu menjawab pertanyaan yang diberikan oleh pendidik (guru) dan menjelaskan fenomena yang dihadapinya. Siswa dapat mencari jawaban dari pertanyaan yang telah diberikan oleh pendidik (guru) secara mandiri atau berkelompok menggunakan pencarian online seperti google scholar atau google search, siswa juga diharapkan menyaring terlebih dahulu jawaban yang ia cari dari berbagai sumber tersebut agar menghasilkan jawaban yang pas. Dalam penerapan yang dilakukan oleh pendidik (guru) kepada siswa bisa membantu meningkatkan kemandirian belajar siswa dan meningkatkan kualitas pembelajaran secara daring (Sunarsi et al., 2020). 


\section{Kesimpulan}

Berdasarkan pemahaman di atas, dapat disimpulkan bahwa peran guru dalam kondisi pandemi Covid-19 sangat diperlukan karena, dapat memotivasi siswa bersemangat dalam belajar dan percaya diri atas kemampuannya, siswa dapat menyelesaikan masalah - masalah yang terjadi pada saat proses pembelajaran secara daring. Pada saat proses pembelajaran secara daring, siswa diharapkan mempunyai kemandirian dalam belajar. Kemandirian belajar pada siswa masih menjadi permasalahan dalam pembelajaran. oleh karena itu, siswa dituntut untuk mulai belajar mandiri. Dengan belajar mandiri, siswa dapat beraktivitas tanpa bergantung terhadap orang lain. Untuk meningkatkan kemandirian belajar siswa tersebut, pendidik (guru) bisa memakai metode pembelajaran inkuiri dalam pembelajaran daring ini dengan cara : a. Siswa dianjurkan dalam mengamati fenomena kejadian yang memberikan pengalaman belajar; b. Pendidik memberikan pertanyaan kepada siswa mengenai fenomena yang di hadapi dari berbagai sumber; c. Pendidik mengajukan pertanyaan kepada siswa untuk melatih berfikir dalam melakukan penalaran mengenai pertanyaan yang diberikan oleh pendidik; d. Mengumpulkan pertanyaan - pertanyaan yang diajukan oleh pendidik; e. Membuat kesimpulan berdasarkan pertanyaan yang di berikan oleh pendidik yang telah diolah.

\section{Ucapan Terima Kasih}

Ucapan terimakasih saya berikan kepada Bapak Maskhur Dwi Saputra selaku Dosen Penulisan Ilmiah yang telah memberikan bimbingan, saran dan arahan atas terbuatnya artikel ini.

\section{Referensi}

Arif, M. Z., Soeryanto, \& Yunus. (2021).Strategi Mengembangkan Kemandirian Belajar Mahasiswa Jurusan Teknik Mesin Di Masa Pandemi Covid 19. JVTE (Journal Of Vocational And Technical Education, 3(2), 2-9.

Asmuni. (2021). Penerapan Model Pembelajaran Inkuiri Berbasis Google Classroom untuk Meningkatkan Kemampuan Berfikir Kritis dan Aktivitas Belajar PAI dan Budi Pekerti pada Siswa SMA Negeri 1 Selong. Jurnal Teknologi Pendidikan: Jurnal Penelitian dan Pengembangan Pembelajaran, 6(1), 26 - 35.

S, Rahmayanti., \& W, Budhi. (2017). Pengaruh Model Pembelajaran Inkuiri Terhadap Hasil Belajar IPA Ditinjau Dari Kemandirian Belajar Siswa. Jurnal: Jurnal Ilmiah Pendidikan IPA, 4(2), 34-40.

Damayanti, I. (2017). Penerapan Model Pembelajaran Inkuiri Untuk Meningkatkan Hasil Belajar Mata Pelajaran IPA Sekolah Dasar. Jurnal Ilmiah Sekolah Dasar, 1(1), 20.

Erita, E. (2017). Pengaruh Model Pembelajaran. Economica, 6(1), 72-86.

Suarsana,I. N., Suharsono, N.,\& Warpala, I. W. S. (2019). Pengaruh Model Pembelajaran Inkuiri Terbimbing Terhadap Kemandirian Belajar Dan Prestasi Belajar. Jurnal: Jurnal Pendidikan dan Pembelajaran IPA Indonesia, 9(1), 34-42.

Nurgiyantari, V. I. D., Wahyuni, S., \& Totalia, S. A. (2018). Penerapan Inkuiri untuk Meningkatkan Kemandirian dan Hasil Belajar Siswa Kelas X Pemasaran 3 SMK Negeri 3 Surakarta. Jurnal Pendidikan Bisnis Dan Ekonomi, 4(1). 
Nuriali, W., Busnawir, Samparadja, H \& Ili, L. (2018). Pengaruh Model Pembelajaran Inkuiri Terbimbing Terhadap Kemampuan Berpikir Kritis Matematika Ditinjau Dari Kemandirian Belajar Siswa Smk. Jurnal Pembelajaran Berpikir Matematika, 38(2), 53-64.

Rahmawati, T., Utami, L., \& Refelita, F. (2019). Perbandingan Model Problem Based Learning Dan Inkuiri Terbimbing Terhadap Keterampilan Berpikir Kritis Siswa. JTK (Jurnal Tadris Kimiya), 4(1), 21-32.

Suarsana, I. N., Suharsono, N., \& Warpala, I. W. S. (2017). Pengaruh Model Pembelajaran Inkuiri Terbimbing Terhadap Kemandirian Belajar Dan Prestasi Belajar Biologi Siswa Kelas XI SMA Negeri 1 Kubu. Jurnal: Jurnal Teknologi Pembelajaran Indonesia, 7(2), 4754.

Saputra, N., Kosilah \& Wedyawati, N. (2020). Efektivitas Metode Pembelajaran Inkuiri Berbasis Web Terhadap Kemandirian Belajar Siswa Di Rumah. Prosiding: Seminar Nasional IImu Pendidikan Dan Multi Disiplin, 72-76.

Subekti, F. E., \& Yunuarto, W. N. (2008). Peningkatan Kemandirian Belajar Dan Kemampuan Komunikasi Matematika Melalui Pembelajaran S3QR. Jurnal Ilmiah Kependidikan, 2 (1), 1-8.

Sugianto, I., Suryandari, S., \& Age, L. D. (2020). Efektivitas Model Pembelajaran Inkuiri terhadap Kemandirian Belajar Siswa di Rumah. JIP (Jurnal Inovasi Penelitian), 1(3), 159170.

Sulistyawati, T. E. (2020). Perspektif Aksiologi Terhadap Penurunan Minat Belajar Anak di Masa Pandemi. Aksiologi : Jurnal Pendidikan Dan IImu Sosial, 1(1), 33-43.

Sunarsi, D., Wijoyo, H., \& Choir, F. Al. (2020). Implementasi Pembelajaran Online Dalam Masa Pandemik Covid 19. Proseding Seminar Nasional 2020:Penguatan Pendidikan Karakter Pada Era Merdeka Belajar. 411-416. 